\title{
Study on the large-scale development of accounting firms-Based on merger case analysis of Xiamen Tianjian accounting firm
}

\author{
Shi Jinping \\ Address: Room 702, no.22 Jian Fa lv Jiayuan, Binhu south five miles, Xiamen Zip code:361004 Mobile \\ phone:13859995629 \\ E-mail:sjinping@gmail.com
}

\begin{abstract}
At present, the scale of the accounting firms in our country is relatively small in general, which is difficult to contend with the international competitions. Thus, in view of the development need of China's economy and industry, to realize a bigger scale and upper level of accounting firms has been put on the agenda. In that way, whether Chinese local accounting firms exist in an increasing development stage of scale effect? Whether they are suitable for large-scale development? The following parts will analyze and explain them trough cases.
\end{abstract}

Keywords- international competitions; a bigger scale; upper level of accounting firms; large-scale development

\section{I . INTRODUCTION}

China's audit market is a comparable emerging market; while, the market share of the local accounting firms relatively disperses, and it still not formed the position and brand reputation that similar to International Accounting market. Under these circumstances, whether the local accounting firms should develop in large-scale is worthy to researched and discussed.

\section{SCALE DEVELOPMENT PROCESS OF XIAMEN TIANJIAN}

Xiamen Tianjian accounting firm (former Xiamen University accounting firm) was established in October 1988, and ChangXun was the chief accountant. On August 30, 2000, Xiamen Tianjian accounting firm and Xiamen Huatian accounting firm (former Xiamen accounting firm) merged into the Xiamen Tianjian Huatian accounting firm and Huang Shizhong as its chief accountant. After the merger, the operational storage site was moved to 17th and 18th floor of Jin Yuan building, no. 57 Binhu South Road, Xiamen City, Fujian Province. After the establishment, Xiamen Tianjian Huatian accounting firm set up the branch offices in Jiangsu and Fuzhou.

In order to strengthen cooperation and ultimately reach the purpose of "unify standards of practice, professional training, quality control and realize resource sharing, complementary advantages, powerful alliances, and mutual development”, under the leadership of Deputy Finance Minister Zhang Youcai, in June, 2002, Shenzhen Tianjian Xinde, Beijing Tianjian, Zhejiang Tianjian, Xiamen Tianjian Huatian, Chongqing Tianjian and Liaoning Tianjian--the six firms with "Tianjian" in their names set up a loose organization-Tianjian Group. Tianjian group hoped that all the members could abide by the practice guidelines of "independent, objective and impartial", and following the industry purpose of "striving for better quality, credibility, development" and adhering to the spirit of "as heaven maintains vigor through movement, a gentleman should constantly strive for self-perfection” to create the enterprise culture, setting up enterprise brand, pursuing excellence and striving the best, making great effort to build a national brand in Chinese CPA industry.

The chief partners of the six firms have formed the highest authority organization of the group, which was the management committee, and its members respectively were Chen Jianming (Beijing Tianjian), Hu Shaoxian (Zhejiang Tianjian), Huang Shizhong (Xiamen Tianjian), Zhu Qihang (Shenzhen Tianjian), Fu Sifu (Chongqing Tianjian) and Gao Fengyuan (Liaoning Tianjian). The headquartered of the management committee was sited in Beijing with various special committees. There was also a secretariat and two working teams to deal with the daily routine. In addition, six members of the management committee implemented a system of rotating presidency to take charge relatively meetings and other activities. Moreover, the operation of the group followed the principle of "four unified and two independent," that was unified brand, unified standard, unified packaging, unified report forms and independent accounting, independently undertake the civil legal liability. In this group, Beijing Tianjian was the most powerful one and Zhu Qiheng of Shenzhen Tianjian enjoyed the highest prestige. Regrettably, Huang Jianzhong of Xiamen Tianjian left his position to Chen Jianshen and began to work as executive vice president of Xiamen national accounting institute. After he moved to the theoretical research, the practice field lost a master.

In fact, as early as in 1998, the predecessors of Zhejiang Tianjian, Xiamen Tianjian and Liaoning Tianjian had already started a series of cooperation and the plan of setting up a group-based firm has been taken to the agenda. Because of the eventually established time was in 2000, some previous events and meetings were generally considered as the preparatory stages.

As the CICPA's statistics showed that the totally yearly income of six firms of "Tianjian” in 2004 has exceeded 250 million Yuan, which was much higher than the local rank first accounting firm named Lixin Changjiang. Among them, Beijing Tianjian owned the largest business and its total 
income for 2004 has reached 70.67 million Yuan, representing a growth rate as high as $80 \%$ and ranking 13th of the industry; Followed by Zhejiang Tianjian with total revenue of 6,366 million, ranking 16th. In addition, Xiamen Tianjian, Chongqing Tianjian, Shenzhen Tianjian and Liaoning Tianjian were ranked 55th, 58th, 63rd and 91st respectively.

In July 2004, the third session of second enlarged meeting of Tianjin Group adopted the application of Hong Kong He Xilin accountant firms joined into the group, which was called Hong Kong Tianjian. There were more than 80 employees at that time in He Xilin accountant firms, among which, forty people had professional qualifications, including the Hong Kong certified public accountant of UK, Chinese Certified Public Accountant, Australian Certified Public Accountant and secretary union members Hong Kong companies. In that way, Tianjian Group finally established vigorously.

But the good situations did not last long. On March 19, 2005, the leader of Tianjian Group firstly betrayed Tianjian and joined into the group of Deloitte gloriously, and on June 1, 2005, Beijing Tianjian fully integrated into Deloitte. However, this merger between Deloitte and Beijing Tianjian really had some hidden secrets. The original customer of Beijing Tianjian, China Minsheng Banking Corp. Ltd, has changed to hire PricewaterhouseCoopers as the cooperation partner, which because the SFC required the accountant company should one of the China's A-share listing firm; and if the company need to refinance of the listed companies, it should be audited by a well-known foreign accounting firm. For the Beijing Tianjian, losing a big customer was a very painful thing. Now Beijing Tianjian also existing business relationship with Communications Bank, but perhaps one day, this customer would be lost. In order to keep these major customers, Beijing Tianjian had to pursue protection from foreign firms. Deloitte also said that this merger was only the first step of its merging plan and the other six firms of Tianjian Group, such as Shenzhen Tianjian, Zhejiang Tianjian, Xiamen Tianjian, etc., would be their next objects.

Deloitte encountered a bit of trouble when implement the plan of merging China's largest accounting firms, "Tianjian", because the second powerful firm of "Tianjian", Zhejiang Tianjian, seemed to be unwilling to accept Deloitte's friendly offer, it was reasonable for it to have such an idea. The relative statistics showed that, in 2004, among all the accounting firms with the securities practice qualification across the country, Zhejiang Tianjian has ranked in the second place. Powerful Zhejiang Tianjian indeed had its plausible reason to refuse Deloitte who had foreign background and had decided to suspend the merger talks with Deloitte. One possible reason for that decision was that the audit that Deloitte did for Kelon was questioned in the industry.

Following Beijing Tianjian, Shenzhen Tianjian successfully merged with Deloitte. On August 4, 2005, the merger agreement was formally signed, which was kept within the firm, Shenzhen Tianjian officially incorporated into Deloitte. Bao Yi, CEO of Deloitte China expressed that: "this merger will further promote our strength in China and solidify our leading position in the field of Chinese audit, consulting, etc. After integration with the Shenzhen Tianjian, Deloitte Shenzhen branch will be the largest accounting firm in Shenzhen.” After the merger, Zhu Qiheng will act as vice chairman of Deloitte China and managing partner of the firm in Shenzhen.

On July 28, 2005, Xinyong Zhonghe accounting firm announced the complete merger with Hong Kong accounting firm in Beijing, becoming the first domestic one who substantially expanded its business to Hong Kong. The two parts made a high profile in Great Hall of the People and the secretary general of CICPA said that "this is a great leap for the mainland accounting firms in the development of internationalization. After the merger, Hong Kong $\mathrm{He}$ Xilin accounting firm would changed to Xinyong Zhonghe ( Hong Kong) accounting firm.

The reason why Xiamen Tianjian was not merged by Deloitte was a bit more dramatic. It was said that Deloitte was very anxious because of the "Kelon" event and it avoided being merged for not setting up branches in threes years. So Xiamen Tianjian had no choice but to find another way out. It was said that it had some contact with BDO for a period of time, but came to nothing at last. Maybe it was because of Chinese ancient idea of "Better be the head of a dog than the tail of a lion" or the high national integrity of not becoming "a slave of a foreign master", Xiamen Tianjian chose to merge others and took the road of their own development and expansion.

In fact, Xiamen Tianjian had a long time substantive contact with Deloitte, but "Kelon” event eventually caused the negotiation to come to an end. Deloitte's merger trip in China had to stop; Through multiple contacts, Xiamen Tianjian seem to have found their own way; in November, 2006, Xiamen Tianjian Huantian accounting firm, Huazheng accounting firm and Beijing Zhongzhou Guanghua accounting firm merged to become Tianjian Zhongzhou(Beijing)accounting firm, with Chen Jianshen as its chief accountant; in June 2007,it invited Hong Kong Deyang accounting firm to join and became the branch in Hong Kang, which made it obtained the audit qualification for Hong Kong stocks, H-Shares and Red chip enterprises. In July 2008, Tianjian Huazheng Zhongzhou(Beijing) accounting firm renamed Tianjian Guanghua (Beijing) accounting firm, and merged Chongqing Tianjian accounting firm in November, 2008. In September 28, 2009, Tianjian Zhengxin accounting firm co., LTD. made a public announcement that Tianjian Guanghua (Beijing) accounting firm co., LTD. and Zhonghe Zhengxin accounting firm co., Ltd.(except business department and branch which joined Xinyong Zhonghe separately) implemented the merger through friendly consultations and shareholders ' approval and renamed "Tianjian Zhengxin accounting firm co.LTD, 
headquartered on 22 floor, Block A of Global Trade Center, no.36, Beisanhuan East Road, Dongcheng District, Beijing. The former Chief partner of Xiamen Tianjian accounting firm, Chen Jianshen, became the chairman of the new board.

Chen Jianshen, male, was born on 20 December 1960 in Nanjing, Jiangsu Province. $\mathrm{He}$ was a non-party representative who graduated from Xiamen University and entitled Ph.D., associate professor, senior accountant, CPA, and senior visiting scholar at the University of Southern California (1997 to 1998). Formerly, he took the position of chairman and chief partner of Xiamen Tianjian Huatian Accounting firm, and now he is the chairman as well as chief partner of Tianjian Zhengxin accounting Co. Ltd. He was the member of the tenth and eleventh national people's political consultative conference committee. At present, he is the standing director of China institute of certified public accountants and member of Auditing Standards Board, Professional technical committee and Expert Consultative Committee. He is also nominated to the consultant expert in China Accounting Standards Committee, member of China Securities Regulatory Commission restructuring expert advisory committee, vice chairman of Financial Accounting Committee of the Securities Association of China, director of accounting society of china vice chairman of the audit committee, editor of "Accounting Research", Visiting Professor for Management School of Xiamen University, Accounting School of Dongbei University of Finance and Economics and Xiamen National Accounting Institute; he was appointed consecutively for three times as member of Major mergers and reorganization audit committee of CSRC, and worked as the first Chinese members of the International Auditing Standards Committee (IAPC)from 2000 to 2002 (altogether 14 members in this Committee in the world). He is one of the representative figures who are active in both accounting and auditing practice academia, and also widely recognized by senior experts in that industry .

In May 1, 2012, Jingdu Tianhua accounting firm merged with Tianjian Zhengxin accounting firm. After the merger, Xuhua who was in Jingdu Tianhua became the chief partner and Chen Jianshen was the partner and chairman of managing committee of Zhi Tong accounting firm. In May, 2012, former Jingdu Tianhua accounting co. Ltd. decided to rename "Zhi Tong accounting firm (special ordinary partnership)"and officially began using the new name on June 18, 2012.

In fact, as early as in October 2009, the Jingdu Tianhua firm joined international firms - Grant Thornton International, which was the only member in China. Grant Thornton International originated from an accounting firm established in Chicago in 1924, whose members were from 110 countries and regions across the world. With professional services network composed of more than 2,500 partners and 30,000 employees, this firm can provide personalized service of seamless connectivity to customers around the world. Grant Thornton International's global revenue in 2010 reached $\$ 3.7$ billion, in which the audit revenue was \$ 1.7 billion. Therefore, Grant Thornton International started to use the new name "Zhi Tong International” in June, 2012.

\section{SCALE DEVELOPMENT ANALYSIS OF XIAMEN TIANJIAN}

After the merger, Zhi Tong accounting firm headquartered was sited in Beijing, and has a solid foundation in all-important economic centers. It set up offices in Xiamen, Changchun, Chengdu, Guangzhou, Nanjing, Qingdao, Shanghai, Taiyuan, Wuhan and Hong Kong. At present, Zhi Tong has about 2,400 employees and more than 120 partners, including more than 700 certified public accountants. There are numbers of foreign partners and staff from member firm of Grant Thornton, who have good insight into the United States, international industry standards and overseas capital markets experience. Zhi Tong has 15 offices in China, covering major areas across the country and provides no time difference international professional services for more than 170 listed companies, nearly 2,000 state-owned enterprises, private enterprises and foreign-invested enterprises.

Among the partners of Zhi Tong accounting firm, there are scholars and professors from domestic well-known colleges and universities, and there are also many people who has written or translated a lot of professional books, as well as senior experts who worked as top manager at famous companies in accounting and assets appraisal industry. Some of the partners worked at professional committees such as the standing council of China association of certified public accountants, Auditing Standards Board, and so on. Some others served as members at China Accounting Standards Committee, issuance examination committee of China Securities Regulatory Commission, GEM issuance examination committee of the China Securities Regulatory Commission, and so on. There are also some partners who once worked at State-owned enterprises board of supervisors sent by the State Council.

All employees in Zhi Tong have received professional training in accounting as well as auditing and have a deep understanding of international accounting standards and international accounting practices, most of whom can skillfully apply foreign languages. In addition, there are also a group of senior professionals who once worked in the four big international accounting firms for many years and have provided strong professional support for promoting the development of the internationalization process. After the merger, Zhi Tong has reached the leading level of domestic local CPA in the aspects of business scale, professionals, service network, quality of service and the overall strength. They have obtained securities and futures qualifications, large state-owned enterprises to audit business qualification, financial related business audit qualification, corporate bankruptcy case manager qualification, qualifications for 
Asset assessment and land assessment, engineering cost consulting, and so on. Zhi Tong accounting firm ranked 9 in mainland China in 2012 with the income of about 587 million Yuan.

Table 3.1 Annual revenue details of Xiamen Tianjian and the merged firms

Unit: Ten thousand Yuan

\begin{tabular}{|c|c|c|c|c|c|}
\hline Year & Name of the fim & Income & CPAnumber & Per capita income & Ranking \\
\hline 1999 & $\begin{array}{l}\text { Xiamen Tianjian } \\
\text { accourting fim }\end{array}$ & $1,485.29$ & 42 & 35.36 & 33 \\
\hline 1999 & \begin{tabular}{|l|} 
Xiamen Huatian \\
accourting fim
\end{tabular} & 876.00 & 27 & 32.44 & 77 \\
\hline 2002 & $\begin{array}{l}\text { Xiamen Tianjian Huatian } \\
\text { accourting firm }\end{array}$ & $2,537.37$ & 76 & 33.39 & 54 \\
\hline 2002 & HuaZheng accounting firm & $1,803.43$ & 80 & 22.54 & 80 \\
\hline 2002 & \begin{tabular}{|l|} 
Beijing Zhongzhou \\
Guanghua accounting firm
\end{tabular} & $2,700.77$ & 117 & 23.08 & 45 \\
\hline 2003 & $\begin{array}{l}\text { Xiamen Tianjian Huatian } \\
\text { accourting firm }\end{array}$ & $2,629.00$ & 83 & 31.67 & 61 \\
\hline 2003 & Huazheng accounting firm & $2,823.00$ & 102 & 27.68 & 54 \\
\hline 2003 & $\begin{array}{ll}\text { Beijing } \quad \text { Zhongzhou } \\
\text { Guanghua accounting firm }\end{array}$ & $3,035.00$ & 145 & 20.93 & 48 \\
\hline 2004 & $\begin{array}{l}\text { Xiamen Tianjian Huatian } \\
\text { accounting firm }\end{array}$ & $3,248.00$ & 84 & 38.66 & 55 \\
\hline 2004 & $\begin{array}{|ll|}\text { Huazheng } & \text { Xiamen } \\
\text { Tianjian } & \text { Huatian } \\
\text { accounting firm } & \\
\end{array}$ & $4,035.00$ & 113 & 35.71 & 35 \\
\hline 2004 & $\begin{array}{ll}\text { Beijing Zhongzhou } \\
\text { Guanghua accounting firm }\end{array}$ & $3,130.00$ & 89 & 35.17 & 60 \\
\hline 2005 & $\begin{array}{|lr|}\text { Tianjian } & \text { Huazheng } \\
\text { Zhongzhou } & \text { accourting } \\
\text { firm } & \\
\end{array}$ & $11,054.00$ & 289 & 38.25 & 12 \\
\hline 2005 & $\begin{array}{l}\text { Zhonghe Zhengxin } \\
\text { accounting firm }\end{array}$ & $8,979.00$ & 295 & 30.44 & 16 \\
\hline 2005 & $\begin{array}{ll}\begin{array}{l}\text { Chongqing Tianjian } \\
\text { accounting firm }\end{array} & \\
\end{array}$ & $3,507.00$ & 90 & 38.97 & 59 \\
\hline 2006 & $\begin{array}{lr}\text { Tianjian } & \text { Huazheng } \\
\text { Zhongzhou } & \text { accourting } \\
\text { firm } & \end{array}$ & $11,056.00$ & 294 & 37.61 & 15 \\
\hline 2006 & $\begin{array}{l}\text { Zhonghe Zhengxin } \\
\text { accounting firm }\end{array}$ & $10,854.00$ & 316 & 34.35 & 14 \\
\hline 2006 & $\begin{array}{l}\text { Chongqing Tianjian } \\
\text { accounting firm }\end{array}$ & $3,759.00$ & 92 & 40.86 & 59 \\
\hline 2007 & $\begin{array}{|lr|}\text { Tianjian } & \text { Huazheng } \\
\text { Zhongzhou } & \text { accounting } \\
\text { firm } & \\
\end{array}$ & $15,995.00$ & 269 & 59.46 & 16 \\
\hline 2007 & \begin{tabular}{|l|} 
Zhonghe Zhengxin \\
accounting firm
\end{tabular} & $14,687.00$ & 379 & 38.75 & 15 \\
\hline 2007 & \begin{tabular}{|l|l|} 
Chongqing Tianjian \\
accourting fim
\end{tabular} & $5,310.00$ & 98 & 54.18 & 51 \\
\hline 2008 & \begin{tabular}{|l|} 
Tianjian Guanghua \\
accounting firm
\end{tabular} & $23,944.00$ & 402 & 59.56 & 12 \\
\hline 2008 & \begin{tabular}{|l|} 
Zhonghe Zhengxin \\
accourting firm
\end{tabular} & $19,675.00$ & 430 & 45.76 & 15 \\
\hline 2009 & $\begin{array}{|lr|}\text { Tianjian Zhengxin } \\
\text { accourting fim }\end{array}$ & $38,758.00$ & 702 & 55.21 & 13 \\
\hline 2010 & \begin{tabular}{|l|} 
Tianjian Zhengxin \\
accounting firm
\end{tabular} & $44,226.20$ & 795 & 55.63 & 14 \\
\hline 2010 & \begin{tabular}{|l|l|} 
Jingdu & Tianhua \\
accourting firm & \\
\end{tabular} & $34,679.00$ & 482 & 71.95 & 16 \\
\hline 2011 & Zhi Tong accounting firm & $58,781.37$ & 701 & 83.85 & 13 \\
\hline
\end{tabular}

The original data sources:Chinese Institute of Certified Public Accountants

website,website:http://www.cicpa.org.cn/,2002-2012 top 100 firms information,writer:Chinese Institute of Certified Public Accountants,time:July, 2012:

From Table 3.1, it can also be clearly seen that weighted average of the per capita income of CPAs in the accounting firm which were involved in the merger has increased significantly than before after the merger. For example, in
2008, weighted average per capita income of the certified public accountants in the involved two firms before Zhonghe Zhengxin was 524,300 Yuan, and the per capita income of certified public accountants in Tianjian Zhengxin accounting firm was 552,100 Yuan with an increase of 27,000 Yuan; for another example, in 2010, before the merger of Tianjian Zhengxin and Jingdu Tianhua, the weighted average per capita income of the certified public accountants in the involved two firms was 617,900 Yuan and the per capita income of certified public accountants in merged Zhi Tong accounting firm was 838,500 Yuan with an increase of 220,600 Yuan; the scale effect of the merger is obvious.

Table 3.2 Number of CPA and firms in China from 2001to 2011

Unit:Ten thousand Yuan

\begin{tabular}{|l|l|l|l|l|l|}
\hline Year & $\begin{array}{l}\text { The total revenue of the } \\
\text { industry }\end{array}$ & CPAnumber & $\begin{array}{l}\text { Number of } \\
\text { fims }\end{array}$ & $\begin{array}{l}\text { Per capita } \\
\text { income }\end{array}$ & $\begin{array}{l}\text { Fim average } \\
\text { income }\end{array}$ \\
\hline 2001 & & $55,897.00$ & $4,287.00$ & & \\
\hline 2002 & $1,100,000.00$ & $56,940.00$ & $4,402.00$ & 19.32 & 249.89 \\
\hline 2003 & $1,270,000.00$ & $61,255.00$ & $4,779.00$ & 20.73 & 265.75 \\
\hline 2004 & $1,540,000.00$ & $65,385.00$ & $5,405.00$ & 23.55 & 284.92 \\
\hline 2005 & $1,830,000.00$ & $69,283.00$ & $5,355.00$ & 26.41 & 341.74 \\
\hline 2006 & $2,210,000.00$ & $72,048.00$ & $6,458.00$ & 30.67 & 342.21 \\
\hline 2007 & $2,790,000.00$ & $77,345.00$ & $7,012.00$ & 36.07 & 397.89 \\
\hline 2008 & $3,100,000.00$ & $85,855.00$ & $7,284.00$ & 36.11 & 425.59 \\
\hline 2009 & $3,170,000.00$ & $91,149.00$ & $7,605.00$ & 34.78 & 416.83 \\
\hline 2010 & $3,750,000.00$ & $96,498.00$ & $7,785.00$ & 38.86 & 481.70 \\
\hline 2011 & $4,360,000.00$ & $98,674.00$ & $8,066.00$ & 44.19 & 540.54 \\
\hline
\end{tabular}

The original data sources: Chinese Institute of Certified Public Accountants

website,website:http://www.cicpa.org.cn/,2002-2012 top

100 firms information,writer: Chinese Institute of

Certified Public Accountants,time:July, 2012:

One of the indicators to measure the size of an accounting firm is business income. Under normal circumstances, the CPA business income can best reflect the size of the firm. How much the revenue is can generally reflect how much business a firm can undertake, and the more the income of an accounting firm is, the stronger its ability of dispersing and bearing the risk is. Therefore, in the usual cases, the scale of business income is most appropriate indicator to reflect the scale of an accounting firm, which is why the international authoritative institutions take income as a major international business accounting standard in the company ranking.

In table 3.3, we can see from the Top 100 accounting firms information published by the Certified General Accountants Association that along with the merge process, the revenue size of Xiamen Tianjian accounting firm increased rapidly year by year. 
Table 3.3 Xiamen Tianjian annual income growth after the merger

Unit:Ten thousand Yuan

\begin{tabular}{|l|l|l|l|l|l|}
\hline Year & Name of the firms & Income & CPAnumber & Per capita income & Ranking \\
\hline 1999 & $\begin{array}{l}\text { Xiamen Tianjian accounting } \\
\text { fim }\end{array}$ & $1,485.29$ & 42 & 35.36 & 33 \\
\hline 2002 & $\begin{array}{l}\text { Xiamen Tianjian Huatian } \\
\text { accounting fim }\end{array}$ & $2,537.37$ & 76 & 33.39 & 54 \\
\hline 2003 & $\begin{array}{l}\text { Xiamen Tianjian Huatian } \\
\text { accounting fim }\end{array}$ & $2,629.00$ & 83 & 31.67 & 61 \\
\hline 2004 & $\begin{array}{l}\text { Xiamen Tianjian Huatian } \\
\text { accourting fim }\end{array}$ & $3,248.00$ & 84 & 38.66 & 55 \\
\hline 2005 & $\begin{array}{l}\text { Tianjian Huazheng Zhongzhou } \\
\text { accourting fim }\end{array}$ & $11,054.00$ & 289 & 38.25 & 12 \\
\hline 2006 & $\begin{array}{l}\text { Tianjian Huazheng Zhongzhou } \\
\text { accounting fim }\end{array}$ & $11,056.00$ & 294 & 37.61 & 15 \\
\hline 2007 & $\begin{array}{l}\text { Tianjian Huazheng Zhongzhou } \\
\text { accounting fim }\end{array}$ & $15,995.00$ & 269 & 59.46 & 16 \\
\hline 2008 & $\begin{array}{l}\text { Tianjian Guanghua accounting } \\
\text { fim }\end{array}$ & $23,944.00$ & 402 & 59.56 & 12 \\
\hline 2009 & $\begin{array}{l}\text { Tianjian Zhengxin accounting } \\
\text { fim }\end{array}$ & $38,758.00$ & 702 & 55.21 & 13 \\
\hline 2010 & $\begin{array}{l}\text { Tianjian Zhengxin accounting } \\
\text { fim }\end{array}$ & $44,226.20$ & 795 & 55.63 & 14 \\
\hline 2011 & \begin{tabular}{l} 
Zhi Tong accounting fim \\
\hline
\end{tabular} & $58,781.37$ & 701 & 83.85 & 13 \\
\hline
\end{tabular}

The original data sources: Chinese Institute of Certified Public Accountants

website,website:http://www.cicpa.org.cn/,2002-2012 top

100 firms information,writer:Chinese Institute of

Certified Public Accountants,time:July, 2012:

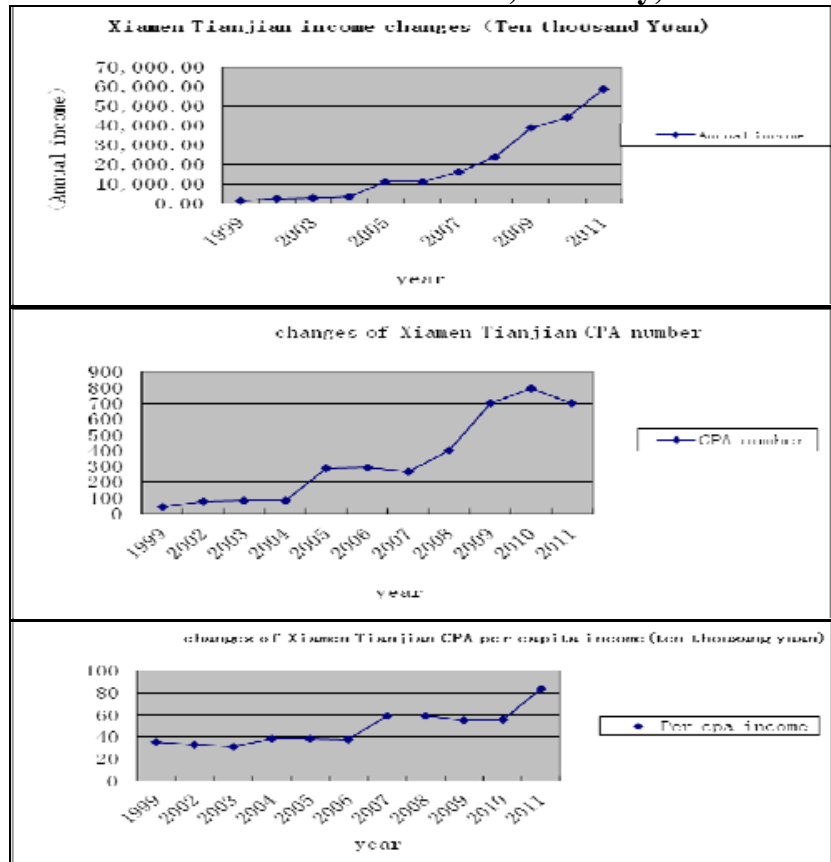

From Table 3.3 we can see that, through mergers, the income scale of Xiamen Tianjian accounting firm grow rapidly from less than 15 million Yuan in 1999 to 587 million Yuan in 2011, which increased 38 times during the twelve years; the number of CPA increase from 42 in 1990 to 701 in 2011, which increased 16 times, and the increase of annual income was 22 times more than that of CPA. The extent of increase in income is far greater than the staff increase and CPA's per capita income is also showing a clear upward trend; although the per capita change in market share of CPA was deducted, CPA's per capita income in Xia Tianjian accounting firms is still very obvious; in recent years, the number China's practice of certified public accountants increased rapidly with the growth speed near that of total revenue of Certified public accountants. China's average per capita income of each certified public accountant shows a smooth upward trend, which is shown in the following figure:

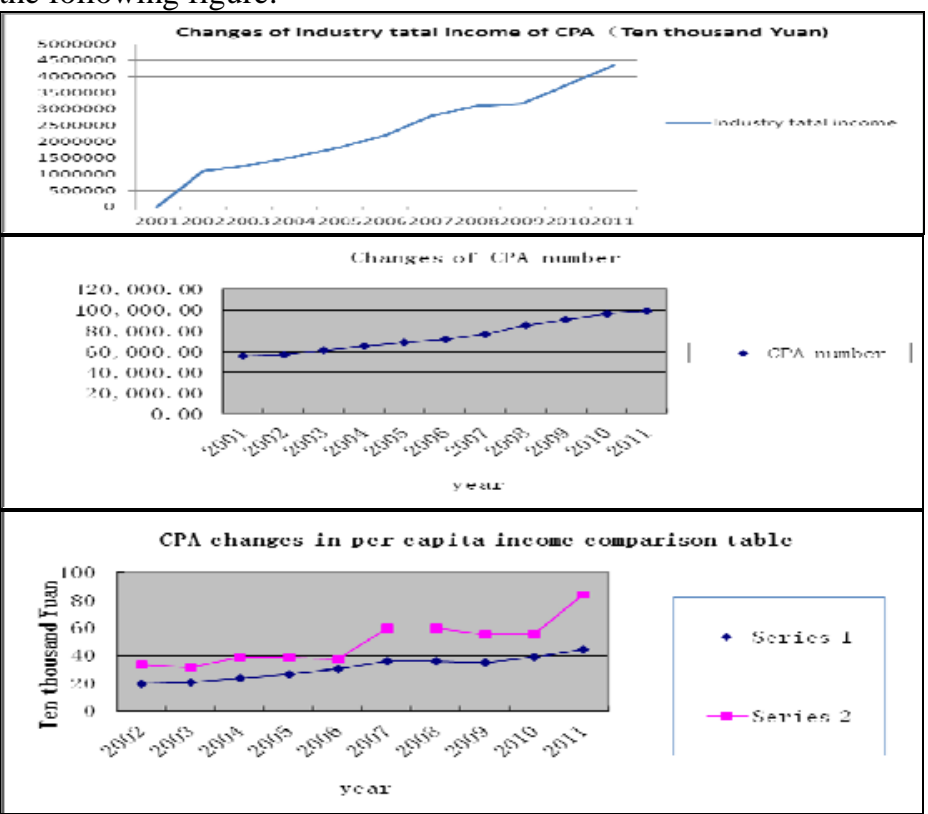

\section{Note:Series 1 is per capita income of Tianjian accounting firm, and series 2 is the national Certified Public Accountant average income.}

\section{IV.CONCLUSION}

To sum up, in the process of merger over these years, the scale reward for Xiamen Tianjian is at the increasing stage as the scale rises. The extent of Income growth is larger than that of the size, that is to say, its efficiency is constantly improving, showing clear scale effect. At present, large scale development is the better choice for Xiamen Tianjian accounting firm. As special service enterprises, the size of the scale is usually reflected by the indicators of the registered capital, number of CPA, business revenue, market share, number of branches, the breadth of distribution areas, and so on. Internal drive of any economic organization scale development is the existence of economies of scale in the certain extent and certain scope. Large accounting firms can mitigate market risks and are better equipped to meet the challenges and withstand competition from domestic and foreign counterparts

\section{REFERENCES:}

[1] Chang Xun. Management and operation question of accounting firms $[\mathrm{M}]$.Beijing:Economic science publishing house,2009.

[2] Chinese Institute of Certified Public Accountants.Industry development research data of Chinese certified public accountants 
[J] .Economic science publishing house,2005.

[3] Chinese Institute of Certified Public Accountants website, 2002 -2012 top 100 accounting firms information,2013-2-26.

[4] Ministry of Finance of the People's Republic of China. Opinions on accelerating the development of China's CPA industry [J] .Accounting Research,No.10, 2009.

[5] Liu Yuting. A new milestone in the process of the reform and development of China's CPA industry — Analysis of Opinions on accelerating the development of China's CPA industry $[\mathrm{J}]$.Accounting Research,No. 10, 2009. 